\title{
Comparison of Physical Activity in Obese and Non-Obese Women and Investigation of the Relationship between Physical Activity with ABO Blood Groups and Rh factor
}

\author{
Serpil Cecen (Corresponding author) \\ Marmara University, Pendik Research and Education Hospital Sports Physiology, \\ Istanbul, Turkey \\ Email: drserce@gmail.com \\ ORCID NO: 0000-0002-7908-5208 \\ Canan Eren \\ Marmara University Pendik Research and Education Hospital Microbiology, \\ Istanbul, Turkey
}

\begin{abstract}
Introduction: Decreased physical activity is an important risk factor for obesity. The International Physical Activity Questionnaire (IPAQ) has been developed to determine physical activity levels. Previous studies showed that obesity is affected by ABO blood types.

Aim of the study was to search whether blood groups are associated with the level of physical activity. If proven, this will indicate that the blood groups may be one of the genetic factors that influence inclination towards obesity.
\end{abstract}

Material and Methods: The study included 306 ( $n=211$ obese, $n=95$ nonobese) female between the ages of 18 and 65 years. Body weights, BMI (body mass index) fat percentage, fat mass and fat-free mass were determined by using bio-impedance device. The short (IPAQ-S) and long form of (IPAQ-L) questionnaire was implemented through personal interview. ABO and Rh blood groups were determined via Microplack method.

Results: No significant difference for IPAQ-S (vigorous, moderate, walking, sitting time, total physical activity) between obese and nonobese groups. However, the activity level of nonobese group was detected higher than obese group. According to IPAQ-L only significant difference in house yard-work detected higher in the obese group. There was no significant result obtained in evaluation of IPAQ-S and IPAQ-L by ABO blood groups in obese and nonobese group. There was no significant outcome detected in $\mathrm{Rh}$ factor and IPAQ-S in obese and nonobese group; however, a significant outcome was detected in IPAQ-L.

Conclusion: Lack of significant findings in obese and nonobese groups in terms of physical activity levels according to IPAQ-S and IPAQ-L in the study reminds that obesity cannot be explained by physical activity alone. We could not detect a significant association between ABO blood groups and physical activity. Furthermore, the present study indicated that explaining obesity and physical activity in association with a single factor is difficult.

Key Words: Obesity, physical activity, ABO blood groups, Rh factor

Special Issue of Health Sciences

DOI: $10.7176 /$ JSTR/6-03-05 


\title{
Obez ve Obez Olmayan Kadınlarda Fiziksel Aktivitenin Karşılaştırılması ve ABO Kan Grupları ile Rh Faktörü ile Fiziksel Aktivite Arasındaki İlişsinin Araştırılması
}

\section{Özet}

\begin{abstract}
Amaç: Fiziksel aktivite azalmasının obezitede önemli bir risk faktörü olduğu bilinmektedir. Uluslararası Fiziksel Aktivite Anketi (IPAQ) fiziksel aktivite düzeylerini belirlemek amaciyla geliştirilmiştir. Obezitenin kan gruplarından etkilendiği daha önceden yapılan çalışmalarda gösterilmiş olup, bu çalışmamızda amacımız kan gruplarının fiziksel aktiviteyi etkileyip etkilemediğini araştırmaktır. Kanıtlanırsa eğer, kan gruplarının obeziteye eğilimi etkileyen genetik faktörlerden biri olabileceğini düşünmek mümkün olabilir.
\end{abstract}

Gereç ve Yöntemler: Çalışmaya 18-65 yaş arası 306 kadın ( $0 \mathrm{bez}=211$, obez olmayan=95) katıldı. Boy uzunlukları ölçüldükten sonra biioimpedans cihazında kilo, beden kitle indeksi, yağ yüzdesi, yağ ağırlığı, yağsız ağırlık tesbit edildi. Uluslararası Fiziksel Aktivite Anketi kısa ve uzun form yüzyüze görüşmeyle birebir uyguland1.kan grubu tayini Kan Bankasında Microplack metodu ile saptandı.

Bulgular: Uluslararası Fiziksel Aktivite Anketi kısa formda (şiddetli, orta dereceli fizik aktivite, yürüme, oturma süresi, total fiziksel aktivite) obez ve obez olmayan grupta anlamlı bir sonuç elde edilemedi.Fakat aktivite seviyesi obez olayan grupta obezlere göredaha yüksek bulundu.Uzun formda ev-bahçe işlerinin obez grupta istatistiksel olarak anlamlı derecede yüksek olduğu tesbit edildi. Uzun ve kısa formda ABO kan gruplarına göre obez ve obez olmayan grupta istatistiksel olarak anlamlı bir fark elde edilemedi.Rh faktörüne göre obez ve obez olmayan grupta kısa formda anlamlı bir sonuç elde edilemezken, uzun formda anlamlı sonuç elde edildi.

Sonuç: Kısa ve uzun formda fiziksel aktivite açısından obez ve obez olmayan grupta anlamlı sonuç elde edememiş olmamız obezitenin tek başına fiziksel aktivite ile açıklanamayacağını düşündermektedir. ABO kan grupları ile fiziksel aktivite arasında anlamlı bir sonuç elde edemedik. Bu çalışmamız obezite ile fiziksel aktivite arasındaki ilişkinin tek faktörle açıklanmasının güç olduğunu göstermektedir.

Anahtar Kelimeler: Obezite; fiziksel aktivite; ABO kan grupları; Rh faktörü

\begin{abstract}
Introduction
Increase number of obese people is observed globally (1). It has been shown that sedentary lifestyle is associated with obesity, diabetes, cardiac diseases $(2,3)$ and decrease in physical activity is an important risk factor for obesity (4). There are a number of studies indicating a negative association between physical activity and body mass index $(\mathrm{BMI})(5,6)$. Association between obesity and chronic diseases such as diabetes, cardiac diseases (7), and cancer (8) show that regular physical exercise is protective against chronic diseases (9). Several studies on obese individuals have demonstrated that physical activity cause long term weight loss and prevent weight regaining $(10,11)$

The International Physical Activity Questionnaire (IPAQ) has been developed by Craig et al. to determine physical activity levels of participants between 15 and 65 years of age (12). Validity and reliability study of short and long form of IPAQ was performed by Saglam et al. in Turkey (13). The short form provides information about walking, moderate and vigorous activities whereas the long form as well as covering these activities it provides information about occupational activity, transportation, house-yard work and leisure time activities (12).

ABO blood groups have been identified first by Karl Landsteiner in 1901 (14): Although there are studies on physiological functions of blood groups, this topic remains a mystery. Previous studies demonstrated associations between ABO blood groups and diabetes (15), obesity (16), cancer (17) and venous thrombosis (18). Previous studies showed that obesity is affected by ABO blood groups; however, the mechanism could not be clarified completely. The aim of the present study was to search whether
\end{abstract}

28 | $P$ a g e

www.iiste.org 
blood groups are associated with the level of physical activity. If proven, this will indicate that the blood groups may be one of the genetic factors that influence inclination towards obesity.

\section{Material and Methods}

The study included 306 female outpatients including 211 participants in the obese group and 95 participants in the control group between the ages of 18 and 65 years. The age average was $33 \pm 7.7$ in the obese group and $30 \pm 7.6$ in the non-obese group; mean height of the obese group was $160 \pm 6.2$ whereas the mean height of the non-obese group was $161 \pm 6.3$. Body height of the participants was measured on a flat surface without shoes and socks. Body weights, BMI, fat percentage, fat mass and fat-free mass of the patients were determined through a bio-impedance device (Tanita-BC418). Individuals with a BMI level below $25 \mathrm{~kg} / \mathrm{m}^{2}$ are defined as normal weight whereas those with a BMI level between 25 and 30 $\mathrm{kg} / \mathrm{m}^{2}$ are defined as overweighed and individuals with a BMI over $30 \mathrm{~kg} / \mathrm{m}^{2}$ are defined as obese ${ }^{19}$. One group of subjects included 95 individuals with a normal ranged BMI levels whereas another group consisted of 211 individuals with abnormal BMI (obese group, BMI $>30 \mathrm{~kg} / \mathrm{m}^{2}$ ) levels.

The short and long form of "International Physical Activity Questionnaire" (IPAQ) adopted to Turkish was implemented through personal interview on voluntary basis. The short form ( 7 questions) provides information about the time spent for walking, moderate and vigorous activities. The time consumed for sitting is evaluated as a separate question. Calculation of total score of the short form includes addition of period (minutes) and frequency (days) of walking, moderate and vigorous activities. Such calculations revealed a score as MET-minute. One MET-minute is calculated by multiplication of the activity performed with MET score. Walking was 3.3 MET, moderate physical activity was 4.0 MET, and vigorous physical activity was 8.0 MET. Physical activity levels were divided into three levels as physically inactive $(<600 \mathrm{MET}-\mathrm{min} /$ week), minimally active (600-300 MET min/week) and sufficiently active ( $>3000 \mathrm{MET} \mathrm{min} /$ week). Those with any disorder that may prevent physical activity were excluded (13).

After collection of $2 \mathrm{ml}$ of blood into EDTA from each patient, ABO and Rh blood groups were determined via Microplack method as forward-reverse.

\section{Approval of the Ethical Committee}

The present study was approved by the Research Ethics Committee of Faculty of Medicine within Marmara University (Ethics decision number:09.2015.151). The participants were informed that their participation is completely voluntary; and written consent was obtained from each participant.

\section{Statistical Analysis:}

The participants data collected within the study were analyzed through package program of IBM Statistical Package for the Social Sciences (SPSS) for Windows 20.0. Since Kolmogorov-Smirnov and Shapiro-Wilk test results for age and height parameters of the subjects are $p>0.05$, age and height parameters were found to be normal distribution (Table 1). In the analysis of the results, parametric tests were applied and it was seen that there was a statistically significant difference between the groups in terms of their age in the Independent Sample $T$ test results according to their age and height $(\mathrm{p}<0,05)$. Mann Whitney U-test was applied to determine whether there was a difference between physical activity scores of individuals according to obesity status. (Tables 4 and 5). Pearson correlation test was applied to show the relationship between anthropometric measurements and physical activities of the subjects and $p<0.05$ data was accepted as significant. (Table 6). The Mann Whitney U test was used to evaluate whether there was any difference on the short and long-term physical activity scores of the Rh status (Tables 7 and 8).

\section{Results}

The results of normality test for individuals' ages and height are given in Table 1. It was found that there was a statistically significant difference between the groups in terms of the age of the individuals and the mean age of the obese group was older than the non-obese group (Table 2).

A statistically significant difference was detected between obese and non-obese groups in terms of age, weight, BMI, fat percentage, fat mass, fat free mass. Weight, BMI, fat percentage, fat mass and fat free mass were higher in obese group (Table 3). Mann Whitney U-test was used to evaluate whether there was a difference between physical activity scores of individuals according to obesity status. The evaluation results are shown in Tables 4 and 5 above. There was no significant difference for short term (IPAQ-S) physical activity scores (vigorous, moderate, walking, sitting time, total physical activity). However, the activity level of non-obese group was detected to be higher than obese group. Obese and 
non-obese groups were determined as different in activity levels (Table 4). According to IPAQ-L there was a statistically significant difference in moderate and house yard-work activity were detected higher in the obese group, but occupational activity and sitting time were detected higher in the nonobese group (Table 5).

Table 1. Results of normality test for participants age and height

\begin{tabular}{|l|l|l|l|l|l|l|}
\hline & \multicolumn{4}{|l|}{ Kolmogorov-Smirnov } & \multicolumn{4}{l|}{ Shapiro-Wilk } \\
\cline { 2 - 7 } & Statistics & DF & $\mathrm{p}$ & Statistics & DF & $\mathrm{p}$ \\
\hline Age & 0.047 & 306 & 0.099 & 0.988 & 306 & 0.075 \\
\hline Height & 0.069 & 306 & 0.051 & 0.989 & 306 & 0.060 \\
\hline
\end{tabular}

DF: Degree of freedom

Table 2. Independent sample $\mathrm{T}$ test results for the age and size of the participants according to their groups

\begin{tabular}{|l|l|l|l|l|l|}
\hline \multirow{2}{*}{ Grup } & $\mathrm{N}$ & Mean & SD & $\mathrm{p}$ \\
\hline \multirow{2}{*}{ Age } & Obese & 211 & 33.7 & 7.7127 & \multirow{2}{*}{$0.002 *$} \\
\cline { 2 - 6 } & Nonobese & 95 & 30.7 & 7.6108 & \\
\hline \multirow{2}{*}{ Height } & Obese & 211 & 160.0 & 6.2773 & \multirow{2}{*}{0.190} \\
\cline { 2 - 6 } & Nonobese & 95 & 161.0 & 6.2321 & \\
\hline
\end{tabular}

SD: Standart Deviation

Table 3. Anthropometric measurements of the obese and nonobese groups

\begin{tabular}{|l|l|l|l|}
\hline \multirow{2}{*}{} & Obes Group $(\mathrm{n}=211)$ & Nonobese Group $(\mathrm{n}=95)$ & \multirow{2}{*}{ P value } \\
\cline { 2 - 3 } & Mean \pm SD & Mean \pm SD & \\
\hline Weight $(\mathrm{kg})$ & $89.7 \pm 22.1$ & $56.2 \pm 10.1$ & $0.000^{*}$ \\
\hline BMI $\left(\mathrm{kg} / \mathrm{m}^{2}\right)$ & $34.9 \pm 7.7$ & $21.3 \pm 3.1$ & $0.000^{*}$ \\
\hline \% Fat & $40.7 \pm 6.8$ & $23.9 \pm 7.0$ & $0.000^{*}$ \\
\hline Fat Mass $(\mathrm{kg})$ & $37.6 \pm 15.4$ & $14 \pm 7.0$ & $0.000^{*}$ \\
\hline Fat Free Mass $(\mathrm{kg})$ & $52 \pm 7.5$ & $41.6 \pm 3.9$ & $0.000^{*}$ \\
\hline
\end{tabular}

BMI: Body mass index

Table 4. Activity scoring of obese and nonobese groups according to IPAQ-S

\begin{tabular}{|l|l|l|l|}
\hline \multirow{2}{*}{ IPAQ-S } & Obese Group (n=211) & $\begin{array}{l}\text { Non-obese Group } \\
(\mathrm{n}=95)\end{array}$ & \multirow{2}{*}{ P value } \\
\cline { 2 - 3 } & Mean Rank & Mean Rank & \\
\hline Vigorous PA & 150.8 & 159.4 & 0.19 \\
\hline Moderate PA & 148.1 & 165.4 & 0.02 \\
\hline Walking PA & 150.5 & 159.9 & 0.39 \\
\hline Sitting time/min/day & $147.4 \mathrm{~min} /$ day & $166.8 \mathrm{~min} /$ day & 0.07 \\
\hline Total PA & $147.4 \quad 166.9$ & 0.07 \\
\hline Activity Level & $144.4 \quad 173.6$ & $\mathbf{0 , 0 0 4 *}$ \\
\hline
\end{tabular}

PA: Physical Activity 
Table 5. Activity scoring of obese and non-obese groups according to IPAQ-L

\begin{tabular}{|l|l|l|l|}
\hline \multirow{2}{*}{ IPAQ-L } & Obese Group $(\mathrm{n}=211)$ & Non-obese Group $(\mathrm{n}=95)$ & \multicolumn{2}{l|}{ P value } \\
\cline { 2 - 4 } & Mean Rank & Mean Rank & 0.77 \\
\hline Vigorous PA & 152.7 & 155.2 & $\mathbf{0 . 0 0 2 *}$ \\
\hline Moderate PA & 164.1 & 129.9 & 0.13 \\
\hline Walking PA & 148.4 & 164.7 & $\mathbf{0 . 0 0 0}$ \\
\hline Occupational PA & 142 & 179 & 0.60 \\
\hline Transportation PA & 155.2 & 149.6 & $\mathbf{0 . 0 0 0}$ \\
\hline House-yard work PA & 165.7 & 126.2 & 0.13 \\
\hline Leisure time PA & 158.3 & 142.6 & $\mathbf{0 . 0 2 9 *}$ \\
\hline Sitting time, min/day & 146 minute /day & 169 minute /day & 0.74 \\
\hline Total PA & 154.6 & 151 & 0.72 \\
\hline Activity Level & 154.1 & 150.5 & \\
\hline
\end{tabular}

PA: Physical Activity

There was no statistically significant result detected in evaluation of the short-term physical activity questionnaire in terms of weight, BMI, fat percentage, fat mass and fat free mass.

A statistically significant result was detected in evaluation of the short-term physical activity questionnaire in terms of weight, BMI, fat percentage, fat mass and fat free mass. It was also detected that moderate physical activity, house yard-work increase and walking and occupational activity decrease by weight gaining whereas moderate physical activity, house yard-work activity increase and walking activity decrease by increase of BMI; walking activity decreases and house-yard work activity increases by fat percentage and fat mass; and moderate physical activity as well as house-yard work activity increase by fat free mass increase (Table 6).

Table 6. Activity scoring regarding antropometric measurements according to IPAQ-L

\begin{tabular}{|c|c|c|c|c|c|c|c|c|c|c|}
\hline \multirow{2}{*}{$\begin{array}{l}\text { IPAQ-L } \\
(n=306)\end{array}$} & \multicolumn{2}{|c|}{ Weight } & \multicolumn{2}{|l|}{ BMI } & \multicolumn{2}{|l|}{ Fat $\%$} & \multicolumn{2}{|c|}{ Fat Mass } & \multicolumn{2}{|c|}{ Fat Free Mass } \\
\hline & $\mathrm{r}$ & $\mathrm{p}$ & $\mathrm{r}$ & $\mathrm{p}$ & $\mathrm{r}$ & $\mathrm{p}$ & r & $\mathrm{p}$ & $\mathrm{r}$ & $\mathrm{p}$ \\
\hline Moderate PA & 0.18 & 0.001 & 0.13 & 0.025 & 0.081 & 0.160 & 0.102 & 0.076 & 0.12 & 0.039 \\
\hline Walking PA & -0.14 & 0.017 & -0.14 & 0.015 & -0.16 & 0.005 & -0.14 & 0.012 & 0.090 & 0.114 \\
\hline Occupational PA & -0.23 & 0.000 & -0.096 & 0.093 & -0.101 & 0.078 & 0.085 & 0.136 & 0.049 & 0.397 \\
\hline House-yard work & 0.17 & 0.002 & 0.17 & 0.002 & 0.13 & 0.021 & 0.14 & 0.012 & 0.14 & 0.014 \\
\hline
\end{tabular}

PA: Physical Activity

There was no statistically significant result obtained in evaluation of short- and long-term physical activity by $\mathrm{ABO}$ blood groups in the obese and non-obese group.

There was no statistically significant outcome detected in evaluation of $\mathrm{Rh}$ factor and short-long term physical activity questionnaires in the obese and non-obese group; however, a statistically significant outcome was detected in evaluation of long-term physical activity. Higher vigorous physical activity and occupational activity were detected in $\mathrm{Rh}$ positive individuals when compared with $\mathrm{Rh}$ negative individuals in the obese group (Table 7). Higher occupational activity and activity levels were detected in $\mathrm{Rh}$ positive individuals when compared with $\mathrm{Rh}$ negative individuals in the non-obese group (Table 8). 
Table 7. Comparison of long term activity values of the obese group according to Rh factor

\begin{tabular}{|l|l|l|l|}
\hline \multirow{2}{*}{ IPAQ-L } & \multicolumn{2}{|l|}{ Obese Group $(\mathrm{n}=211)$} & \multirow{2}{*}{ P value } \\
\cline { 2 - 3 } & Rh Positive $(\mathrm{n}=188)$ & Rh Negative $(\mathrm{n}=23)$ & \\
\cline { 2 - 3 } & Mean Rank & Mean Rank & \\
\hline Vigorous PA & 108.4 & 85.6 & $\mathbf{0 . 0 3 7 *}$ \\
\hline Moderate PA & 106.4 & 102.6 & 0.782 \\
\hline Walking PA & 107.8 & 90.9 & 0.211 \\
\hline Occupational PA & 108.7 & 83.3 & $\mathbf{0 . 0 3 0}$ \\
\hline Transportation PA & 107.9 & 97.1 & 0.459 \\
\hline House-yard work PA & 104.6 & 116.8 & 0.367 \\
\hline Leisure time PA & 104.7 & 116 & 0.384 \\
\hline Sitting time, min. & 105.8 & 107.3 & 0.913 \\
\hline Total PA & 107.5 & 93 & 0.280 \\
\hline Activity Level & $108.8 \quad 72.9$ & $\mathbf{0 . 0 1 0}$ \\
\hline
\end{tabular}

PA: Physical Activity

Table 8. Comparison of long term activity values of the non-obese group according to Rh factor

\begin{tabular}{|l|l|l|l|}
\hline \multirow{2}{*}{ IPAQ-L } & \multicolumn{2}{|l|}{ Non-obese Group $(\mathrm{n}=95)$} & \multirow{2}{*}{ P value } \\
\cline { 2 - 3 } & Rh Positive $(\mathrm{n}=78)$ & Rh Negative $(\mathrm{n}=17)$ & \\
\cline { 2 - 3 } & Mean Rank & Mean Rank & 0.105 \\
\hline Vigorous PA & 49.7 & 39.8 & 0.471 \\
\hline Moderate PA & 48.9 & 43.6 & 0.070 \\
\hline Walking PA & 50.3 & 37.0 & $\mathbf{0 . 0 2 6}$ \\
\hline Occupational PA & 50.8 & 34.8 & 0.204 \\
\hline Transportation PA & 49.6 & 40.3 & 0.722 \\
\hline House-yard work PA & 48.4 & 45.8 & 0.422 \\
\hline Leisure time PA & 49.0 & 43.3 & 0.884 \\
\hline Sitting time, min & 47.8 & 48.8 & $\mathbf{0 . 0 4 3}$ \\
\hline Total PA & 50.6 & 35.7 & 0.103 \\
\hline Activity Level & 49.9 & 39.0 & \\
\hline
\end{tabular}

PA: Physical Activity

\section{Discussion}

In the present study, no statistically significant result was detected weight, BMI, fat percentage, fat mass, fat free mass according to IPAQ-S. Also there was no statistically significant result ABO blood groups and $\mathrm{Rh}$ factor according to IPAQ-S. But there was significant difference between activity level of the obese and non-obese groups according to IPAQ-S.

A statistically significant result was detected in evaluation of weight, BMI, fat percentage, fat mass and fat free mass according to IPAQ-L. It was also detected that moderate physical activity, house-yard work increase and walking and occupational activity decrease by weight gaining whereas moderate physical activity, house-yard work increase and walking activity decrease by increase of BMI; walking activity decreases and house-yard work increases by fat percentage and fat mass; and moderate physical activity as well as house-yard work increase by fat free mass increase.

There was no difference for ABO blood groups except a difference for Rh factor according to IPAQ-L. Higher vigorous physical activity and occupational activity were detected in Rh positive individuals when compared with Rh negative individuals in the obese group. Higher occupational activity and total activity were detected in $\mathrm{Rh}$ positive individuals when compared with $\mathrm{Rh}$ negative individuals in the non-obese group.

The association of physical activity with obesity:

Varying outcomes were obtained in diverse studies through IPAQ-S in different countries. A study 
conducted in Iran and Saudi Arabia showed that physical activity of middle-age women have insufficient physical activity (20), whereas Southern Asian women were shown to be inactive when compared with Caucasian population (21). Hallal et al. conducted a study on 3,182 women and detected that the physical inactivity frequency was $41.1 \%$; physical activity was positively associated with age and socio-economic state, and it was reversely associated with self-reported health state ${ }^{22}$. Another study detected that obesity is common and physical activity level is lower in individuals with lower socio-economical levels (23). Another study conducted on college students did not find an association between physical activity and BMI (24). The people living in Santa Catarina, Joaçaba, Brasil were shown to have lower physical activity level when compared with other regions (25). A systematic study showed that there was no consisted association between physical activity and continuity of the body weight (26). Despite this review study, many previous studies indicate that physical inactivity increases the risk of obesity (27). The data obtained from several above mentioned studies relate physical inactivity to social environment, cultural differences, economic status, working status, awareness on activity, overall attitudes and behaviors of the individual (28-30).

We conclude that detection of an increase in moderate activity, house-yard work and a decrease of occupational activity and walking activity in proportion with weight increase in the data obtained by IPAQ-L may due to the study group including house wives who do not work. We observe that women mostly spend time at home rather than the outdoor activities. Lack of a significant difference in terms of such activities and total physical activity in the obese and non-obese groups may be since obesity may not be explained by physical activity alone. Although different activity levels were shown in different occupation fields in previous studies, the association with obesity was not shown in these studies $(31,32)$. A study conducted on middle-aged women did not detect any association between BMI and physical activity (33). Lack of a significant association between obese and non-obese groups in the present study confirms that physical activity cannot be explained by a single factor. The data obtained from the studies up to data show the necessity to detailed studies on physical activity and obesity.

\section{The association of physical activity and $\mathrm{ABO}$ blood groups as well as Rh factor:}

We did not obtain a significant association between ABO blood groups and physical activity in the obese and non-obese groups. However, a previous study carried out with athletes showed that the athletes with O-blood group present a better performance than other non-O blood groups (34). It was shown that $\mathrm{O}$ blood group is more in Elite Water polo players (35). In research involving blood groups and obesity, it has been established that the lowest rates of obesity (16), venous thrombosis (36) and cancer risk (37) exist in blood group 'O'. It is therefore necessary to study physiological mechanisms of blood groups that underlie this interesting phenomenon.

Significant results in $\mathrm{Rh}$ factor in the obese and non-obese groups according to IPAQ-L detected in the present study may be considered that Rh factor may be an important element. Although the information obtained about the location of $\mathrm{Rh}$ antigens increased, studies about physiological functions of these were not clarified yet (38). Limited information about association between Rh factor and physical activity in the literature reveals the requirement of further studies to be conducted on this topic. Detailed studies to understand the effect of $\mathrm{Rh}$ and $\mathrm{ABO}$ antigens on human health are needed. We believe that the data obtained from this study would enlighten further studies.

\section{Conclusion}

Lack of significant findings in the obese and non-obese groups in terms of physical activity levels according to IPAQ-A and IPAQ-L in the present study reminds that obesity cannot be explained by physical activity alone. We could not detect a significant association between ABO blood groups and physical activity. Furthermore, the present study indicated that explaining obesity and physical activity in association with a single factor is difficult.

Author Disclosure Statement

No conflicting financial interests exist.

\section{References}

1- Swinburn B, Egger G, \& Raza F (1999) Dissecting obesogenic environments: the development and application of a framework for identifying and prioritizing environmental interventions for obesity. Prev Med 29:563-70. DOI: 10.1006/pmed.1999.0585. 
2- Hu FB, Li TY, Colditz GA,Willett WC \& Manson JE (2003).Television watching and other sedentary behaviors in relation to risk of obesity and type 2 diabetes mellitus in women. Journal of American Medical Association , 289:1785-1791. DOI: 10.1001/jama.289.14.1785.

3- Warren TY, Barry V, Hooker SP, Sui X, Church TS \& Blair SN (2010). Sedentary behaviors increase risk of cardiovascular disease mortality in men. Medicine and Science in Sports and Exercise, 42:879-885. doi: 10.1249/MSS.0b013e3181c3aa7e.

4- Dalene KE, Anderssen SA, Andersen LB, Steene-Johannessen J, Ekelund U, Hansen BH \& Kolle E (2018). Secular and longitudinal physical activity changes in population-based samples of children and adolescents. Scand J Med Sci Sports , 28(1):161-71. doi:10.1111/sms.12876.

5- Clement JM, Schmidt CA, Bernaix, LW, Cowington NK \& Carr TR.(2004) Obesity and physical activity in college women: implications for clinical practice. J Am AcadNurse Pract, 16:291-99. https://doi.org/10.1111/j.1745-7599.2004.tb00452.x.

6- Anding JD, Suminski RR \& Boss L (2001).Dietary intake, body mass index, exercise, and alcohol: are college women following the dietary guidelines for Americans? J Am Coll Health, 49:167-71. DOI: $10.1080 / 07448480109596299$.

7- Said S, Mukherjee D \& Whayne TF (2016).Interrelationships with Metabolic Syndrome, Obesity and Cardiovascular Risk. Curr Vasc Pharmacol, 14(5):415-25.

8- De Pergola G \& Silveseris F (2013). Obesity as a major risk factor for cancer. J Obes, 291546. doi: 10.1155/2013/291546. doi: 10.1155/2013/291546. Epub 2013 Aug 29

9-Jakicic JM, \& DavisKK (2011). Obesity and physical activity. Psychiatr Clin North Am, 34(4):82940. doi: 10.1016/j.psc.2011.08.009. Epub 2011 Oct 15.

10- Slentz CA, Duscha BD, Johnson JL, Ketchum K, Aiken LB, Samsa GP, Houmard JA, Bales CW $\&$ Kraus WE (2004). Effects of the amount of exercise on body weight, body composition, and measures of central obesity: STRRIDE-arandomized controlled study. Arch Intern Med, 2004;164: 31-9. doi:10.1001/archinte.164.1.31.

11- Unick JL, Jakicic JM \& Marcus BH (2010).Contribution of behavior intervention components to 24 month weight loss. Med Sci Sports Exerc, 42:745-53. doi: 10.1249/MSS.0b013e3181bd1a57.

12- Craig CL, Marshall AL, Sjöström M, Bauman AE, Booth ML, Ainsworth BE, Pratt M, Ekelund U, Yngve A, Sallis JF \& Oja P. (2003).International Physical Activity Questionnaire:12-Country Reliability and Validity. Medicine Science and Sports Exercise, 35:1381-95. doi: 10.1249/01.MSS.0000078924.61453.FB.

13- Sağlam M, Arıkan H, Savcı S, Ince DI, Güçlü MB, Karabulut E \& Tokgozoğlu L. (2010). International physical activity questionnaire: reliability and validity of the turkish version. Perceptual and Motor Skills 111:1. DOI 10.2466/06.08.PMS.111.4. ISSN 0031-5125.

14- Farhud DD \& Zarif Yeganeh M (2013). A brief history of human blood groups. Iran Journal of Public Health 42(1):1-6.

15- Chuemere AN, Olorunfemi OJ, Nwogu JU, Mmom OF, Agbai EO \& Vurey VV (2015). Correlation between Blood group, Hypertension,Obesity, Diabetes, and combination of Prehypertension and Pre- Diabetes in School Aged Children and Adolescents in Port Harcourt. J Dent Med Sci, 14: 83-9. DOI: 10.9790/0853-141268389.

16- Eren C \& Çeçen S (2018). An Analysis on theAssociation Between ABO and Rh Blood Groups with Obesity. Proc. Natl. Acad. Sci. India. Sect. B Biol. Sci, 1-6. doi:10.1007/s40011-018-10292 . 
17- Mandato VD, Torricelli F, Mastrofilippo V, Ciarlini G, Pirillo D, Farnetti E, Fornaciari L, Casali B, Gelli MC, Abrate M, Aguzzoli L, Battista La Sala G \& Nicoli D (2017). Prognostic impact of $\mathrm{ABO}$ blood group on type I endometrial cancer patients-results from our own and other studies. J Cancer, 23:2828-35. doi: 10.7150/jca.19524.

18- Franchini M \& Lippi G (2016). Relative Risks of Thrombosis and Bleeding in Different ABO Blood Groups. Semin Thromb Hemost, 42:112-7. DOI: 10.1055/s-0035-1564832.

19- Slipko Z, Latuchowska B \& Wojtkowska E (1994). Body structure and ABO and Rh blood groups blood group in patients with advanced coronary heart disease after aortocoronary by-pass surgery. Pol Arch Med Wewn, 91:55-60.

20- Emdadi S, Hazavehei SMM, Soltanian AR, Bashirian S \& Moghadam RH (2016). Physical Activity Status and Related Factors among Middle-Aged Women in West of Iran, Hamadan: A Cross-Sectional Study. Global Journal of Health Science, 8(10);151159.doi:10.5539/gjhs.v8n10p151.

21- Curry WB \&Thompson JL (2015). Comparability of accelerometer- and IPAQ-derived physical activity and sedentary time in South Asian women: A cross-sectional study. Eur J Sport Sci. 15(7):655-62. doi: 10.1080/17461391.2014.957728. Epub 2014 Sep 24.

22- Hallal PC, Victora CG, Wells JC \& Lima RC (2003). Physical inactivity: prevalence and associated variables in Brazilian adults. Med Sci Sports Exerc. 35(11):1894-900. doi: 10.1249/01.MSS.0000093615.33774.0E

23- Santos R, Aires L, Santos P, Ribeiro JC \& Mota J (2008). Prevalence of overweight and obesity in a Portuguese sample of adults: results from the Azorean Physical Activity and Health Study. Am J Hum Biol, 20:78-8. /doi.org/10.1002/ajhb.20680.

24- Üçok K, Genç A, Şener Ü, Akkaya M \& Mollaoğlu H (2011). Investigation of Physical Activity Level of Medical School Students .Eur J Basic Med Sci, 1 (1):33-38.

25- Baretta E, Baretta M \& Peres KG (2007). Physical activity and associated factors among adults in Joaçaba, Santa Catarina, Brazil. Cad Saude Publica, 23:1595-602. DOI:10.1590/s0102$311 \times 2007000700010$.

26- Fogelholm M \& Kukkonen-Harjula K (2000). Does physical activity prevent weight gain - a systematic review. Obes Rev, 1(2):95-111.doi.org/10.1046/j.1467-789x.2000.00016.x.

27- Dumith SC, Hallal PC, Reis RS \& Kohl HW (2011). Worldwide Prevalence of Physical Inactivity and Its Association with Human Development Index in 76 Countries. Prev Med, 53:24-28. http://dx.doi.org/10. 1016/j.ypmed.2011.02.017.

28- Caperchione CM, Kolt GS \& Mummery WK (2009). Physical activity in culturally and linguistically diverse migrant groups to Western Society. Sports Med, 39:167-177. doi: 10.2165/00007256-200939030-00001

29- Underwood M, Satterhtwait LD \& Bartlett HP (2010). Reflexivity and minimization of the impact of age-cohort differences between researcher and research participants. Qual. Health Res, 20:1585-1595. doi: 10.1177/1049732310371102.

30- Yates T, Davies MJ \& Gray LJ (2010). Levels of physical activity and relationship with markers of diabetes and cardiovascular disease risk in 5474 white European and South Asian adults screened for type 2 diabetes. Pev. Med, 15:290-294. oi.org/10.1016/j.ypmed.2010.06.011.

31- Jans MP, Proper KI \& Hildebrandt VH. Sedentary behavior in Dutch workers: differences between occupations and business sectors. Am J Prev Med. 2007;33(6):450-54. DOI: 10.1016/j.amepre.2007.07.033. 
32- Steeves JA, Tudor-Locke C, Murphy RA, King GA, Fitzhugh EC, Harris TB (2015). Classification of occupational activity categories using accelerometry: NHANES 2003-2004. Int J Behav Nutr Phys Act, 12:89. DOI 10.1186/s12966-015-0235-z.

33- Emdadi S, Hazavehie SM, Soltanian A, Bashirian S \& Moghadam RH (2015). Predictive Factors of Regular Physical Activity among Middle-Aged Women in the West of Iran, Hamadan: Application of PRECEDE Model. J Res Health Sci, 15(4):244-9.

34- Lippi G, Gandini G, Salvagno GL, Skafidas S, Festa L, Danese E, Montagnana M, SanchisGomar F, Tarperi C \& Schena F (2017). Influence of ABO blood group on sports performance. Ann Transl Med, 5(12):255. doi: 10.21037/atm.2017.04.33. doi: 10.21037/atm.2017.04.33.

35- Cvjeticanin S \& Marinkovic D (2009). Morphogenetic variability during selection of elite water polo players. J Sports Sci, 27:941-7. doi: 10.1080/02640410902960494.

36- Tirado I, Mateo J, Soria JM, Oliver A, Martínez-Sánchez E, Vallvé C, Borrell M, Urrutia T, Fontcuberta J (2005).The ABO blood group genotype and factor VIII levels as independent risk factors for venous thromboembolism. Thromb Haemost, 93:468-74. doi: 10.1160/TH04-04-0251.

37- Joha HK, Choa E \& Choueirie TK (2012). ABO blood group and risk of renal cell cancer. Cancer Epidemiol, 36(6): 528-532. doi:10.1016/j.canep.2012.07.001.

38- Avent ND \& Reid ME (2000). The Rh blood group system: a review. Blood, 95(2):375-87. 